\title{
Doğurganlık Çağındaki Evli Kadınlarda Genital Hijjen Davranışları ve Cinsel
} Yaşam Kalitesi

\author{
Genital Hygiene Behavior and Quality of Sexual Life in Married Women of \\ Reproductive Age
}

\author{
Nergiz SEVINÇ ${ }^{1}$ (D) Burcu KORKUT ${ }^{2}(\mathbb{D})$, Belgin ORAL ${ }^{3}$
}

\author{
${ }^{1}$ Karabük Üniversitesi Tıp Fakültesi Halk Sağlığı Anabilim Dalı, Karabük, TÜRKiYE \\ ${ }^{2}$ Karabük Toplum Sağlığı Merkezi, Karabük, TÜRKiYE \\ ${ }^{3}$ Sağılık Bilimleri Üniversitesi, Ankara Atatürk Gögüs Hastalıkları ve Gögüs Cerrahisi Sağlık Uygulama ve Araştırma Merkezi, İ̧ \\ Sağlığı ve Hastalıkları Anabilim Dalı, Ankara, TÜRKiYE
}

Öz.

Amaç: Kadın üreme sağlığını doğrudan etkileyen genital hijyen davranışları ve cinsel yaşam kalitesi, Türkiye gibi geleneksel anlayışın hakim olduğu ülkelerde yeterince araştıııımamıştır. Bu çalışmada, doğurganlık dönemindeki kadınların genital hijjen ve cinsel yaşam kalitesinin tespiti ve birbirleriyle olan ilişkinin değerlendirilmesi amaçlandı. Materyal ve Metod: Kesitsel tipteki bu çalışmaya Mart- Nisan 2021 tarihleri arasında Karabük Toplum Sağlığı Merkezine müracaat eden, yaşları 15-49 yaş arası değișen 165 kadın dahil edildi. Katııımcıların sosyodemografik özellikleri değerlendirmek için 11 soru soruldu. Katılımcıların genital hijyen davranışları, 27 sorudan oluşan Genital Hijyen Davranışları Değerlendirme Envanteri ile cinsel yaşam kaliteleri ise 18 sorudan oluşan Cinsel Yaşam Kalitesi Ölçeği ile değerlendirildi. Anket ve ölçekler sanal ortamda katıımcılara uygulandı.

Bulgular: Katılımcıların yaş ortalaması 40 (18-49) yıl idi. Kadınların genital hijyen davranışları envanteri puan ortalaması 56 (30-92) ve cinsel yaşam kalitesi ölçeği puan ortalaması ise 55.6 (23-90) olarak bulundu. Üniversite mezunu kadınlarda, eşi üniversite mezunu olanlarda, çalışan ve ekonomik durumu iyi olanlarda, kırsal kesimde yaşayanlarda ve tek çocuğa sahip kadınlarda her iki ölçek puanları anlamlı olarak yüksek bulundu $(p<0.05)$. Genital hijyen davranışları ile cinsel yaşam kaliteleri arasında pozitif yönlü anlamlı bir korelasyon mevcuttu ( $r: 0.416$, $p<0.001)$.

Sonuç: Kadınların genital hijjen davranışları düşük ve cinsel yaşam kalitesi puanları orta düzeydeydi. Ayrıca her iki ölçek arasında pozitif yönde bir ilişki bulundu. Kadınların genital hijjen konusunda eğitilmesi onların cinsel yaşam kalitelerini olumlu yönde etkileyebilir. Aynı zamanda çiftlere cinsel yaşamın, sağlığın önemli bir parçası olduğunu vurgulayan eğitimlerin mahremiyet koşullarını da dikkate alınarak sağlık kuruluşlarında verilmesi faydalı olabilir.

Anahtar Kelimeler: Genital hijjen, Cinsel yaşam, Kadın sağlığı

Abstract

Background: Genital hygiene behaviors and sexual life quality that directly affect women's reproductive health has not been sufficiently investigated in the countries where traditional understanding is dominant, such as Turkey. In the present study, it was aimed to determine the genital hygiene and sexual life quality of women in the fertilization period and to evaluate their relations with each other.

Materials and Methods: This cross-sectional study included 165 women aged between 15-49 years who applied to a primary health care center in Karabük from March to April 2021. 11 questions were asked to evaluate the sociodemographic characteristics of the participants. The genital hygiene behaviors of the participants were evaluated with the Genital Hygiene Behaviors Evaluation Inventory consisting of 27 questions, and their sexual life quality was evaluated with the Sexual Life Quality Scale consisting of 18 questions. Questionnaires and scales were applied to the participants in the virtual.

Results: The average age of the participants was 40 (18-49) years. Participants' genital hygiene behaviors inventory mean score was 56 (30-92) and the average score on sexual life quality scale was found 55.6 (23-90). Both scale scores were found to be significantly higher in university graduates, women whose husbands are university graduates, working and economically well-off women, living in rural areas, and women with a single child. There was a significant positive correlation between genital hygiene behaviors and sexual life quality ( $\mathrm{r}$ : $0.416, \mathrm{p}<0.001)$.

Conclusion: Genital hygiene behaviors of the women were low and their sexual quality of life scores were moderate. In addition, a positive correlation was found between both the scales. Women being educated on the genital hygiene can positively affect their sexual life quality. At the same time, it may be beneficial to give trainings emphasizing that sexual life is an important part of health for couples, taking into account the privacy conditions in health institutions.

Key Words: Genital hygiene, Sexual life, Women's health
Sorumlu Yazar/Corresponding Author Dr. Nergiz SEvinç

Karabük Üniversitesi Tıp Fakültesi Halk Sağlığı Anabilim Dalı, Balıklar Kayası Mevkii Demir Çelik Kampüsü, Karabük, TÜRKIYE

E-mail: nergizsevinc@karabuk.edu.tr Geliş tarihi / Received: 03.05.2021

Kabul tarihi / Accepted: 05.07.2021

DOI: $10.35440 /$ hutfd.932253 


\section{Giriş}

Epidemiyolojik araştırmalar sonucunda kadınlarda doğurgan çağda görülen önemli sorunlardan birisi de genital enfeksiyonlar olup kadının biyo-psiko-sosyal sağlığını ve yaşam kalitesini etkilemektedir. Kadın sağlığının korunması kadının kendisi için olduğu kadar toplum sağlığı için de büyük önem taşımaktadır (1). Kadınlarda geniş bir mukozal yüzeye sahip olan vajen, hücre yapısı nedeni ile enfeksiyon riskini arttırmakta ve ciddi sekellere neden olmaktadır (2). Ayrıca kadınlarda anatomik olarak vajina, anüs ve üretranın birbirine yakın olması enfeksiyon oluşma ihtimalini daha da artırmaktadır (3).

Kadın üreme sağlığını etkileyen faktörler arasında; genetik ve sosyo kültürel faktörler, doğurganlık, riskli cinsel davranışlar ve ürogenital bölgede hijyen davranış eksiliği yer almaktadır (4). Özellikle vajinal duş uygulaması, rahim içi araç (RIA) kullanmak, mensturasyon döneminde ve perineal tuvalet temizliğinde genital hijyene önem vermemek, uygun iç çamaşırı ve ped kullanmamak kadınlarda görülen diğer riskli genital hijyen davranışları (GHD) arasında yer almaktadır (5). Kadınlarda genital hijyene dikkat edilmediğinde; kötü kokulu vajinal akıntı oluşmakta, cinsel yolla bulaşan hastalıkların oranı artmakta ve hatta kanser vakalarında artış saptanmaktadır. Bu durum ruhsal sorunlara, infertilite korkusunun yaşanmasına ve cinsel yaşam kalitesinde (CYK) azalmaya neden olabilmektedir (6).

Cinsellik biyolojik, psikolojik ve kültürel olguların etkileşimleri sonucunda yaşanan çok parametreli bir olgudur (7). Aynı zamanda bireyin biyolojik yapısını, öğrenme deneyimlerini, örf ve adetleri ile tutum ve davranışlarını kapsamaktadır (8). Cinsel sağlık tüm bireylerin bireysel sağlığı için gerekli, önemli ve pozitif bir parametre olarak kabul edilmektedir. Bu bağlamda üreme ve cinsel fonksiyonları etkileyen organik hastalık ve sakatlıkların bulunmaması, cinsel tepkileri baskılayan ve sosyal ilişkileri olumsuz etkileyen duygu durumlarının olmaması cinsel sağlık olarak tanımlanmaktadır (9).

Cinsellik ve cinsel sağlık kişilerin yaşam koşullarındaki olumlu ya da olumsuz süreçlerden etkilenmekte ve bu durum bireylerin cinsel yaşam kalitesine de yansımaktadır (10). Kadın sağlığının korunması, geliştirilmesi ve olumsuz faktörlerden arındırılması için kadın hijyen ve cinsel yaşam kalitesine yönelik çalışmaların yapılıp eğitimlerin planlaması son derece önemlidir (11). Yapılan literatür taramasında; genital hijyen davranışının, cinsel yaşam kalitesi üzerine etkisini doğrudan konu alan bir çalışmaya rastlanımadı. Bu çalışmada; 18-49 yaş arası doğurganlık dönemindeki kadınların genital hijyen davranışları ile cinsel yaşam kaliteleri arasındaki ilişkinin incelenmesi planlandı.

\section{Materyal ve Metod}

Kesitsel tipteki bu çalışma, Mart- Nisan 2021 tarihlerinde Karabük II merkezinde bulunan Toplum Sağlığı Merkezi'ne (TSM) başvuran 18-49 yaş evli kadınlar ile yapıldı. Belirtilen tarih aralığında TSM 'ye beslenme danışmanlığı, evlilik danışmanlığı ve kanser taraması için ilk kez başvuran 218 kadın çalışmanın evrenini oluşturdu ve örneklem seçimi yapılamayarak tamamı çalışmaya dahil edildi. Çalışmaya katılma gönüllülük esasına dayalı olup katılımcılara önce çalışma hakkında bilgi verildi, sözlü onamları alındı. Çalışmaya katılmayı kabul eden 180 kadına online olarak anket gönderildi. 15 kadının verilerinde eksiklik olduğu için çalışma 165 kadınla tamamlandı.

Anket soruları; 3 bölümden ve toplam 56 sorudan oluştu. Ankete katılan kişilere birinci bölümde yaş, cinsiyet, eğitim düzeyi gibi sosyodemografik özellikler ile ilgili 11 soru, ikinci bölümde Genital Hijyen Davranışları Değerlendirme Envanteri' de (GHDE) yer alan 27, soru üçüncü bölümde ise Cinsel Yaşam Kalitesi Ölçeği'deki (CYKÖ) 18 soru yöneltildi. Araştırma için; Karabük Üniversitesi Girişimsel Olmayan Klinik Araştırmalar Etik Kurulundan (Karar No: 2021/544; Sayı: E-77192459-050.99-24010) ve Karabük il Sağlık Müdürlüğünden (Sayı: E-98024045-604.01.02) onay alındı.

GHDE; Ege ve Eryılmaz tarafından, 15-49 yaş grubu cinsel aktif kadınların genital davranışlarını ölçmek amacıyla geliştirilmiş 4'lü likert tipinde 27 maddeden oluşan bir ölçme aracıdır (12). Ölçekteki her bir ifade 1'den 4'e kadar puanlanmıştır. Olumlu sorular için "hiçbir zaman" yanıtına "1", "bazen" yanıtına "2", "sık sık" yanıtına "3", ve "her zaman" yanıtına "4" puan verilmiştir. Olumsuz sorulara ise "her zaman" yanıtına "1" puan, "sık sık" yanıtına "2", "bazen" yanıtına "3" ve "hiçbir zaman" yanıtına "4" puan verilmiştir. Envanterdeki 17, 26 ve 27. maddeler olumsuz ifadeler içerdiğinden puanlama ters yönde yapılmıştır. Geçerlik ve güvenilirlik çalışması yapılan GHDE' den alınacak en düşük puan 27 , en yüksek puan ise $108^{\prime}$ dir. Envanterin toplam puanı GHD puanını vermektedir. Envanterden alınan puan yükseldikçe GHD’nın istendik düzeyde olduğu şeklinde değerlendirilmiştir. Ölçeğin Cronbach alfa katsayısı 0,86 olarak bulunmuştur (12).

CYKÖ; Symonds ve ark. tarafından 2005 yılında geliştirilmiş olup, ölçeğin Türkçe geçerlilik güvenirliği Tuğut ve Gölbaşı tarafından 2010 yılında yapılmıştır $(13,14)$. Ölçek 18 yaşın üzerindeki tüm kadınlara uygulanabilmektedir. Ölçek 18 maddeden oluşmakta ve altılı likert tipi değerlendirme yapılmaktadır. Her bir maddeyi kadınların son dört hafta içindeki cinsel yaşamlarını düşünerek yanıtlaması beklenmektedir. Ölçekte her bir madde 1-6 ya da 0-5 arasında puanlanmaktadır. Bu çalışmada 1-6 puan sistemi (1=Tamamen katılıyorum, 2=Büyük ölçüde katılıyorum, 3=Kısmen katılıyorum, 4=Kısmen katılmıyorum, 5=Büyük ölçüde katılmıyorum, 6=Hiç katılmıyorum) kullanılmıştır. 1-6'lı puanlama sistemi ile ölçekten alınabilecek puan aralığı 18-108 arasında değişmektedir. Ölçeğin toplam puanı hesaplanmadan önce 1, 5, 9, 13, 18 numaralı maddelerin puanlarının tersine çevrilmesi gerekmektedir. Hangi puanlama sistemi kullanılırsa kullanılsın ölçekten alınan toplam puan 100'e dönüştürülmelidir. Toplam ölçek puanın 100'e dönüştürülmesi için (ölçekten alınan ham puan-18) x100/90 formülünün kullanılması gerekmektedir. Ölçekten alınan puanın 
yüksek olması cinsel yaşam kalitesinin iyi olduğunu göstermektedir. Ölçeğin Cronbach alfa değerini 0.83 olarak belirtilmiştir $(13,14)$.

Araştırma sonunda anket formu aracılığı ile elde edilen veriler Statistical Package for the Social Sciences (SPSS 25.0 IBM Statistics for MAC, Version 25.0) versiyon 25.0 istatistik paket programına girildi. Verilerin kontrolleri ve analizleri aynı programda yapıldı. İstatistiksel analizlerde tanımlayıcı istatistikler için frekans ve yüzde, ortanca, en yüksek ve en düşük değerler kullanıldı. Nicel verilerin istatistiksel analizi için ise normal dağılıma uygunluğuna bakmak için Kolmogorov Smirnov testleri kullanıldı ve bağımlı değişkenler normal dağılıma uymadığı için Mann Whitney $U$, Kruskall Wallis (post hoc Dunn's testi) testleri ile test edilidi. Değişkenler arasındaki ilişkiyi göstermek için Spearman Korelasyon katsayısı kullanıldı. GHDE'nin çalışmamızda Kaiser-Meyer-Olkin (KMO) örneklem uygunluk katsayısı 0.893 ve Barlet-Sphericity testi ki kare değeri 2526.7 $(p<0.001)$ olarak bulundu. Faktör analizi için uygun olduğu görülmüş ve açıklayıcı faktör analizi sonucunda toplam varyansı \%67.7 ve Cronbach alfa iç tutarlık katsayısı 0.92 olarak saptandı. CYKÖ'nin ise çalışmamızda KMO katsayısı 0.939 ve Barlet-Sphericity ki kare değeri $1924.5(p<0.001)$ olarak bulunmuş ve açıklayıcı faktör analizi sonucunda toplam varyansı \% 60.3, Cronbach alfa iç tutarlık katsayısı 0.94 olarak oldukça iyi bir düzeyde tespit edildi. Araştırmada tüm analiz yöntemleri için istatistiksel anlamlılık değerleri $\mathrm{p}<0.05$ olarak belirlendi.

\section{Bulgular}

Çalışmaya katılan 165 kadının yaş ortalaması 36.7 \pm 7.8 (40 \& min-max: 18-49) yıl iken, \%55.2'si ilkokul mezunu ve eşlerinin \%54.4'ünün de ilkokul mezunu olduğu görüldü. Kadınların, \%48.5'i ekonomik durumlarının düşük olduğunu, \%51.5'i ise kırsal kesimde yaşadığını ve \% 61.8'i çekirdek aile yapısında olduğunu belirtti. Katılımcıların \%41.2'si gelir getirici bir işte çalıştığını, \%13.9'u eşinin çalışmadığını bildirdi. Kadınların tamamının en az bir çocuğu olup, \%78.8'inin 2 çocuğu vardı. Görücü usulü ile evlenenlerin oranı ise \%35.8 idi (Tablo 1).

Çalışmamızdaki kadınların GHDE puan ortalamaları 56 (3092) bulundu. Yaş gruplarına ve aile yapısına göre GHDE puanları arasında anlamlı bir fark yok iken $(p>0,05)$ kendisi ve eşleri üniversite mezunu olanlarda, ekonomik durumunu iyi olarak belirtenlerde, kırsalda yaşayanlarda ve çalışan kadınlarda ölçek puanları anlamlı olarak yüksek bulundu. $(p<0,005)$. Eşlerinin çalışma durumlarıla ve herhangi bir kronik hastalığın olup olmamasıyla ölçek puanları arasında anlamlı bir ilişki saptanmadı ( $p>0.05)$. Çocuk sayısı arttıkça GHDE puanlarının da anlamlı olarak düştüğü görüldü $(p<0,05)$ (Tablo 2).

Kadınların CYKÖ puan ortalaması ise 55.6 (23-90) olarak saptandı. CYKÖ puanları en yüksek $25-34$ yaş arasındaki kadınlarda görülmüş ve 18-24 yaş arasındaki kadınlarla is
Tablo 1. 18-49 Yaş Arası Evli Kadınların Sosyo-Demografik Özellikleri

\begin{tabular}{|c|c|c|c|}
\hline \multicolumn{2}{|l|}{ Değişkenler } & n (165) & $\%$ \\
\hline \multirow{3}{*}{ Yaş } & $18-24$ & 14 & 8.5 \\
\hline & $25-34$ & 43 & 26.0 \\
\hline & 35 ve üzeri & 108 & 65.5 \\
\hline \multirow{3}{*}{ Eğitim durumu } & ilkokul & 91 & 55.2 \\
\hline & Orta-lise & 52 & 31.5 \\
\hline & Üniversite & 22 & 13.3 \\
\hline \multirow{3}{*}{ Eşin eğitim durumu } & illkokul & 90 & 54.5 \\
\hline & Orta-lise & 45 & 27.3 \\
\hline & Üniversite & 30 & 18.2 \\
\hline \multirow{3}{*}{$\begin{array}{l}\text { Ekonomik durum (kendi beyanına } \\
\text { göre) }\end{array}$} & Düşük & 80 & 48.5 \\
\hline & Orta & 68 & 41.2 \\
\hline & Iyi & 17 & 10.3 \\
\hline \multirow{2}{*}{ Yaşadığı yer } & Kır & 85 & 51.5 \\
\hline & Kent & 80 & 48.5 \\
\hline \multirow{2}{*}{ Aile tipi } & Çekirdek & 102 & 61.8 \\
\hline & Geniş & 63 & 38.2 \\
\hline \multirow{2}{*}{ Çalışma durumu } & Çalışıyor & 68 & 41.2 \\
\hline & Çalışmıyor & 97 & 58.8 \\
\hline \multirow{2}{*}{ Eşinin çalışma durumu } & Çalışıyor & 142 & 86.1 \\
\hline & Çalışmıyor & 23 & 13.9 \\
\hline \multirow{2}{*}{ Kronik hastalık varlığı } & Evet & 38 & 23.0 \\
\hline & Hayır & 127 & 77.0 \\
\hline \multirow[b]{2}{*}{ Evlenme şekli } & Görücü usulü & 59 & 35.8 \\
\hline & $\begin{array}{l}\text { Kendi } \\
\text { tanışarak }\end{array}$ & 106 & 64.2 \\
\hline \multirow{3}{*}{ Çocuk sayısı } & 1 & 28 & 17.0 \\
\hline & 2 & 130 & 78.8 \\
\hline & 3 ve üzeri & 7 & 4.2 \\
\hline
\end{tabular}

tatistiksel olarak anlamlı farklılık saptandı $(p<0.05)$. Katılımcılardan kendisi ve eşleri üniversite mezunu olanlarda, ekonomik durumunu iyi olarak belirtenlerde ve kırsalda yaşayanlarda, çekirdek aile yapısına sahip olanlarda, tek çocuğa sahip olanlarda ölçek puanları anlamlı olarak yüksek bulundu $(p<0,05)$. Eşlerinin çalışma durumlarıyla ve herhangi bir kronik hastalığın olup olmamasıyla tıpkı GHDE'de olduğu gibi ölçek puanları arasında anlamlı bir ilişki saptanmadı ( $p>0.05$ ) (Tablo 2).

Çalışmamıza katılan kadınların GHD ile CYK arasında pozitif yönlü anlamlı bir korelasyon bulundu ( $\mathrm{r}: 0.416, p<0.001)$ (Tablo3) (Fig1)

\section{Tartışma}

Araştırmamızda kadınların genital hijjen davranışları (GHD) ve cinsel yaşam kalitesi (CYK) puanlarının orta düzeyde olduğu görüldü. Ayrıca GHD ve CYK puanları arasında pozitif yönde korelasyon saptandı.

Çalışmamızdaki kadınların GHDE puan ortalamaları 56 olarak bulundu. Gözüyeşil ve ark.'nın Adanın kırsal bölgesinde kadınlarda yaptıkları çalışmada GHDE puan ortalaması (46) bizim çalışmamıza göre daha düşüktü (15). Öte yandan Çalık ve ark.'nın; 20-49 yaş kadınlarda yaptıkları çalışmada GHDE puan ortalamalarının (70.27) daha yüksek olduğu görüldü (16). Araştırmamızdaki kadınların CYKÖ puan ortalamaları ise 55.6 idi. Unal ve ark.'ları ado lesan annelerde yaptıkları çalışmada CYKÖ puan ortalamasını 44 bulurken; Kaplan ve ark.nın yaptıkları çalışmada kontrol grubu kadınlarda CYKÖ puan ortalamasını 90 idi $(17,18)$. Öte yandan Gölbaşı ve ark.'nın jinekolojik kanserli kadınlarda yaptıkları araştırmada CYKÖ puan ortalamaları bizim sonuçlarımızla 
benzerdi (19). Literatürde bu gibi farklılıkların olması örnekleme alınmış bireylerin sosyodemografik özelliklerinden kaynaklanabilir. Bu çalışmada yaş grupları ile GHDE puanları arasında istatistiksel olarak anlamlı bir farklılık izlenmedi. Kavlak ve ark.nın İzmir'de 135 gebe kadında yaptıkları çalışmada yaş ile GHD arasında ilişki olmadığı saptanmış iken; Çalık ve ark.nın Trabzon'da yaptıkları çalışmada, kadınların yaşlarının artması ile GHD puanlarının düştüğü görülmüştür $(16,20)$. Çalık ve ark.nın buldukları bu sonuç, hem çalışmamızın hem de Kavlak ve ark. yaptıkları çalışma sonuçlarıyla uyumlu değildi. Bu durumun muhtemel nedenleri arasında, katılımcıların eğitim ve sosyokültürel düzeylerin farklı olması ve aynı coğrafik bölgede yaşamamaları olarak gösterilebilir. Ülkemizde kadınlarda yaş gruplarıyla CYKÖ puanlarını değerlendiren kısıtlı sayıda çaIışma yapılmıştır. Tüzmen'nin postpartum dönemdeki kadınlarda yaptığı çalışmada yaşın artması ile CYKÖ puanlarının düştüğü saptamıştır (21).

Tablo 2. 18-49 Yaş Arası Evli Kadınların bazı değişkenlere göre GHDE ve CYKÖ Puanları

\begin{tabular}{|c|c|c|c|}
\hline \multicolumn{2}{|l|}{ Değişkenler } & \multirow{3}{*}{$\begin{array}{c}\text { GHDE } \\
\text { Med (min-max) } \\
51.5 \text { (38-87) }\end{array}$} & \multirow{3}{*}{$\begin{array}{c}\text { CYKÖ } \\
\text { Med(min-max) } \\
41.1(23-75)^{\mathrm{a}}\end{array}$} \\
\hline \multirow{4}{*}{ Yaş } & 18,21 & & \\
\hline & $10-24$ & & \\
\hline & $25-34$ & $56(41-83)$ & $58.9(30-85.60)^{\mathrm{b}}$ \\
\hline & 35 ve üzeri & $56(30-92)$ & $53.9(23-90)^{a, b}$ \\
\hline & & KW:1.480 p:0.477 & KW:8.22 4 p:0.016 \\
\hline \multirow{3}{*}{ Eğitim durumu } & ilkokul & $55(39-87)^{a}$ & $52(24.4-86.7)^{a}$ \\
\hline & Orta-lise & $54(30-75)^{a}$ & $56.2(23.3-85.6)^{a}$ \\
\hline & Üniversite & $72(58-92)^{b}$ & $72(53.3-90)^{b}$ \\
\hline & & KW:41.532 p:0.000 & KW:36.533 p:0.000 \\
\hline \multirow{3}{*}{ Eşin eğitim durumu } & ilkokul & $54(32-82)^{a}$ & $50.6(24.4-86.7)^{\mathrm{a}}$ \\
\hline & Orta-lise & $57(30-87)^{a}$ & $57.8(23.3-85.6)^{\mathrm{a}}$ \\
\hline & Üniversite & $68(41-92)^{b}$ & $68.9(23.3-90)^{\mathrm{b}}$ \\
\hline & & $K W^{*}: 23.230 \mathrm{p}: 0.000$ & KW:18.517 p:0.000 \\
\hline \multirow{3}{*}{ Ekonomik durum (kendi beyanına göre) } & Düşük & $54.5(30-87)^{\mathrm{a}}$ & $52(24.40-85.60)^{\mathrm{a}}$ \\
\hline & Orta & $56.5(38-79)^{\mathrm{a}}$ & $56.15(23.30-90)^{\mathrm{a}, \mathrm{b}}$ \\
\hline & İyi & $69(41-92)^{\mathrm{b}}$ & $67(30-88)^{b}$ \\
\hline & & KW:13.046 p:0.001 & KW:9.585 p:0.008 \\
\hline \multirow{2}{*}{ Yaşadığı yer } & Kır & 61 (41-92) & $58.90(23.30-90)$ \\
\hline & Kent & $53(30-75)$ & $52(23.30-85.60)$ \\
\hline & & $\mathrm{U}^{* *}:-4.897 \mathrm{p}: 0.000$ & U:-2.387 p:0.017 \\
\hline \multirow{2}{*}{ Aile tipi } & Çekirdek & $57(30-92)$ & $58(24-90)$ \\
\hline & Geniş & $54(41-74)$ & $49.5(23-88)$ \\
\hline \multirow{3}{*}{ Çalışma durumu } & & U:-1,574 p:0.115 & U:-2.782 p:0.005 \\
\hline & Çalışıyor & $62(38-92)$ & $60.5(24.4-90)$ \\
\hline & Çalışmıyor & $54(30-87)$ & $52(23.3-88)$ \\
\hline & & U:-3.789 p:0.000 & U:-2.952 p:0.003 \\
\hline \multirow{2}{*}{ Eşinin çalışma durumu } & Çalışıyor & $55.5(30-92)$ & $55(23.3-90)$ \\
\hline & Çalışmıyor & $58(46-68)$ & $55.6(27.8-85.6)$ \\
\hline \multirow{3}{*}{ Kronik hastalık varlığı } & & U:-.756 p:0.450 & U:-.513 p:0.608 \\
\hline & Evet & $54(38-92)$ & $52,6(24-90)$ \\
\hline & Hayır & $57(30-87)$ & $55,6(23-90)$ \\
\hline \multirow{3}{*}{ Evlenme şekli } & & U:1.764 p:0.184 & U:0.089 p:0.766 \\
\hline & Görücü usulü & $55(30-79)$ & $52(23-90)$ \\
\hline & Kendi tanışarak & $56,5(38-92)$ & $57,9(23,3-85,6)$ \\
\hline \multirow{4}{*}{ Çocuk sayısı } & & U:1.866 p:0.062 & U:1.590 p:0.112 \\
\hline & 1 & $72(38-92)^{a}$ & $66.9(37-90)^{\mathrm{a}}$ \\
\hline & 2 & $55(39-74)^{b}$ & $53.3(23.3-86.7)^{b}$ \\
\hline & 3 ve üzeri & $43(30-46)^{c}$ & $45.6(24.4-66.7)^{b}$ \\
\hline \multicolumn{2}{|l|}{ 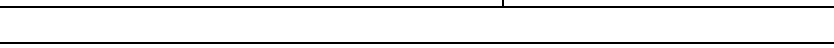 } & $K W=32.506 p: 0.000$ & KW:17.701 p:0.000 \\
\hline
\end{tabular}

CYKÖ: Cinsel Yaşam Kalitesi Ölçeği, GHDE:Genital Hijjen Davranış envanteri, KW*: Kruskall Wallis-H test, U**: Mann-Whitney U test, a,b,c: her sütunda aynı harfi taşımayan gruplar arasındaki fark anlamlı kabul edilmiş aynı harfi taşıyan gruplar arasında fark yoktur, $p<0.05$ anlamlı kabul edildi.

Mestoğulları'nın, 18-49 yaş evli kadınlarda yaptıkları araştırmada, yaş artışının CYK'ni azaltan bir etken olduğunu tespit etmişler (22). Çalışmamıza katılan kadınların CYKÖ puanları en yüksek 25-34 yaş arasındaki kadınlarda görülürken daha genç yaşlarda CYKÖ puanları düşük olduğu tespit edildi. Erken yaşta çocuğa sahip olma ve kadınların evliliğin ilk yıllarında uyum süreçlerinde yaşadıkları zorluklar bu durumun nedenleri arasında düşünülebilir. Literatürde artan eğitim seviyesi ile pozitif yönde ilişkili olarak hem genital hijyen davranışlarının hem de cinsel yaşam kalitesini arttığını gösteren pek çok yayın vardır $(16,19,23)$. Bizim çalışmamızda da literatüre uygun olarak kendisi ve eşleri üniversite mezunu olanların her iki ölçek puanları anlamlı olarak yüksek bulundu $(p<0.001)$. Eğitim seviyesi arttıkça kadınların cinsel yaşam konularında farkındalıklarının olumlu yönde etkilenebileceği gibi; eşler, artan eğitim seviyesi ile cinsel yaşam konularında anlayış ve empati geliştirmiş olabilir. 
Tablo 3. Kadınların Genital Hijjen ile Cinsel Yaşam Kalite Skorları Arasındaki ilişki- Spearman Korelasyon test

\begin{tabular}{|l|c|c|cc|}
\hline & $\mathbf{n}$ & Median (IQR) & $\mathbf{r}$ & $\mathbf{p}$ \\
\hline Genital hijjen & 165 & $56(30-92)$ & 0.416 & 0.000 \\
\cline { 1 - 3 } Cinsel yaşam kalitesi & 165 & $55.60(23.30-90)$ & & \\
\hline
\end{tabular}

IQR: Çeyrekler arası açıklık, n: katılımcı sayısı r: Spearman Korelasyon Test, $p<0.05$ anlamlı kabul edildi.

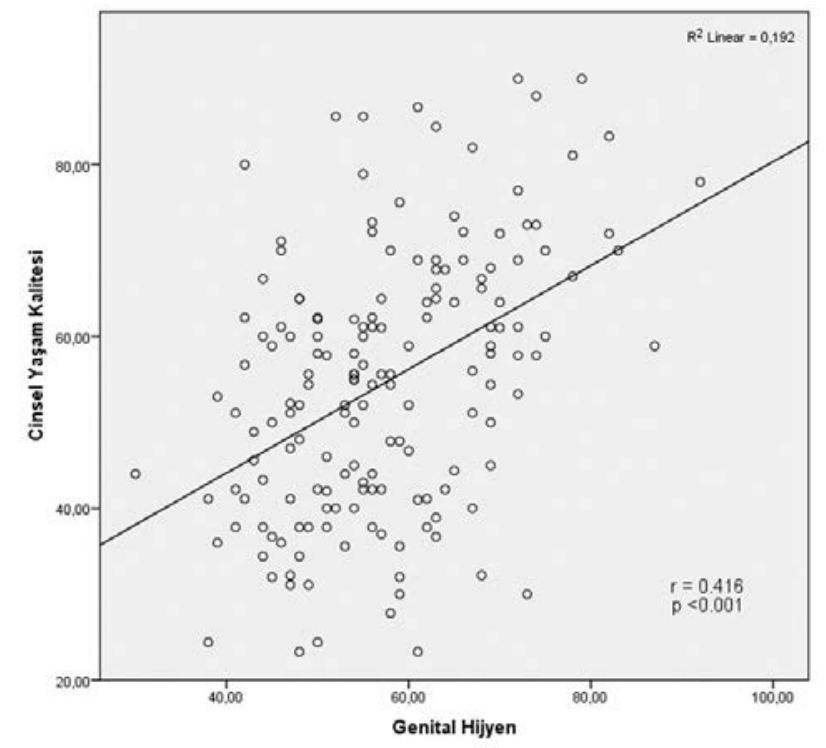

Figure 1. Kadınların cinsel yaşam kalitesi ile genital hijyen davranışları arasındaki pozitif yöndeki ilişkisi

Ekonomik durum bireylerin yaşam kalitesini ve sağlıklarını etkileyen sağlığın önemli bir sosyal belirleyicisidir. CYK ve GHD ile de pozitif bir ilişkisi beklenen bir durumdur. Mali sıkıntılardan uzaklaşmak bireylerde ekonomik güçlüklerin oluşturduğu stresin azalmasını sağlamaktadır. Çalışmamız da ekonomik durumunu iyi olarak belirten grupta her iki ölçek puanları anlamlı olarak yüksek bulundu $(p<0.05)$. Bazı çalışmalarda ekonomik durumun ilişkisi gösterilemese de gelir durumunun hem genital hijyen hem de cinsel yaşam kalitesi için önemli bir belirleyici olduğu gösterilmiştir $(16,23,24)$

Çalışmamızda kırsalda yaşayan kadınlarda her iki ölçek puanları anlamlı olarak yüksekti. Oysaki kentsel alanlarda yaşayan kadınlarda daha yüksek olması beklenirken bu durum kentlerde yaşayan kadınların kent yaşamından olumsuz etkilendiğini düşündürmektedir. Kentlerdeki çevre kirliliği, trafik sorunları, gürültü kirliliği ve hızlı, kalabalık yaşam bu olumsuz etkileri doğurabilir.

Çalışan kadınlarda her iki ölçek puanları yüksek iken $(p<0,05)$ eşlerinin çalışma durumlarıyla ve kronik hastalık durumuyla ölçek puanları arasında anlamlı bir ilişki saptanmadı ( $p>0.05$ ). Çalışmamızla benzer olarak; Çankaya ve ark'ı çalışan kadınlarda GHD davranışlarını daha yüksek bulmuşlardır (24). Yine Çoban ve ark.'nın postpartum dönemdeki kadınlarda yaptıkları araştırmada, çalışan kadınların CYKÖ puanlarını daha yüksek bulmuşlardır (26). Çalışan kadınların ekonomik özgürlüğünün olması ve kendilerini maddi olarak yeterli görmesi cinsel yaşamlarını da olumlu olarak etkileyebilir.

Aile yapısına göre, kadınların GHDE puanları arasında anlamlı bir fark görülmedi ( $p>0.05$ ) Ancak geniş aile yapısına sahip olanlarda CYKÖ puanları daha düşüktü $(p<0.05)$. ÇaIışmamızla benzer olarak Engin ve ark.nın ebelik öğrencilerinde yaptıkları çalışmada aile tipinin GHD puanlarını etkilemediğini gösterilirken; Durmuş ve ark.nın 18 yaş üzeri kadınlarda yaptıkları araştırmada ise geniş aile tipine sahip kadınlarda GHD puanlarının daha düşük olduğu saptanmıştır $(23,24)$. Başkan'nın yaptığı çalışmada geniş aileye sahip kadınların CYK'nin düşük olduğu görülmüştür (27). Öte yandan Selimoğlu ve ark.'nın emziren kadınlarda yaptıkları çalışmada aile tipinin CYK'ni etkilemediği tespit edilmiştir (28). Literatürdeki bu farklılığın sebebi çalışma grubunun demografik özelliklerinin farklılığından kaynaklanabilir. Ayrıca yaşanılan aile tipinin kadınların cinsel yaşamlarında kaliteyi etkileyen önemli bir etmen olduğu düşünülebilir.

Çocuk sayısı arttıkça GHDE puanlarının da anlamlı olarak düştüğü görülürken tek çocuğa sahip kadınlarda CYKÖ puanları daha yüksek bulundu $(p<0,05)$ (Tablo 2). Durmuş ve ark.nın yaptıkları çalışmada çocuk sayısının artmasının GHD’nı olumsuz yönde etkilediği tespit edilmiştir (23). Çocuk sayısının artması; kadınların annelik sorumluluklarının artması anlamına gelmekte ve aile içinde çocukların beslenme, barınma ve sağlık sorunları gibi pek çok görevleri üstlenmeleri ile cinsel yaşamlarında olumsuz sonuçlar doğurabilir.

Çalışmamıza katılan kadınların GHD ile CYK arasında pozitif yönlü bir korelasyon bulundu (r:0.416, p<0.001). Bu da aklımıza genital hijyen davranışlarının olumlu yönde geliştirildiğinde kadınların genitoüriner enfeksiyonlardan korunması ile birlikte cinsel yaşam kalitesinin de artırabileceğini düşündürtmektedir. Literatürde her iki ölçek arasındaki ilişkiyi değerlendiren çalışmaya rastlanmamış olup bu çaIışma için önemli bir sınırlılıktır. Çalışmamızın sonuçları bundan sonraki çalışmalar için yol gösterici olabilir.

Çalışmamızın bazı kısıtlılıkları vardır. Literatürde kadınlarda hem CYKÖ hem de GHDE puanlarını eş zamanlı olarak irdeleyen herhangi bir çalışma olmadığından, sonuçlarımız kısıtlı sayıda çalışma ile karşılaştırıldı. Diğer bir kısıtııık ise çalışmanın tek merkezli olmasıdır.

Sonuç olarak çalışmamızda kadınların GHD ve CYK orta düzeyde bulunmuş olup, konuyla ilgili bilgi verici ve davranış değişikliği oluşturacak eğitimlerin verilmesinin yararlı olacağı düşünülmektedir. Toplum sağlığı merkezlerinde; kadınlara, eşleri ile birlikte mahremiyet garantisinde bilgi ve danışmanlık hizmetlerinin verilmesi kadın sağlığını olumlu yönde geliştirebilir. GHD’nın önemini anlatıcı ve cinsel yaşamın konuşulmaktan çekinildiği bir toplum yapısında olduğumuz için kadınlara her eğitim seviyesinde anlaşılması muhtemel el kitapçıklarının, broşürlerin oluşturulması ve hedef gruba ulaştırılması sağlanmalıdır. Kadın üreme sağlığını etkileyen genital enfeksiyonlardan korunmada etkili olan doğru hijyen davranışlarının kazandırııması, kadınların fiziksel ve ruhsal sağlığını iyileştirmesinin yanı sıra cinsel yaşamlarına da olumlu katkı sağlayabilir. 
Etik onam: Araştırma için; Karabük Üniversitesi Girişimsel Olmayan Klinik Araştırmalar Etik Kurulundan (Karar No: 2021/544; Sayı: E-77192459-050.99-24010) ve Karabük il Sağlık Müdürlügüunden (Sayı: E-98024045-604.01.02) onay alındı.

\section{Yazar Katkıları:}

Konsept: N.S., B.K.

Literatür Tarama: N.S., B.K.

Tasarım: N.S., B.O.

Veri toplama: N.S., B.K.

Analiz ve yorum: N.S., B.O.

Makale yazımı: N.S., B.O., B.K.

Eleştirel incelenmesi: N.S., B.O.

Çıkar Çatışması: Herhangi bir çıkar çatışmamız bulunmamaktadir.

Finansal Destek: Araştırma kapsamında herhangi bir kurum ya da kuruluştan finansal destek sağlanmamıştır.

\section{Kaynaklar}

1. Shah SK, Shrestha S, Maharjan PL, Karki K, Upadhayay A, Subedi $S$, et al. Knowledge and Practice of Genital Health and Hygiene among Adolescent Girls of Lalitpur Metropolitan City, Nepal. American Journal of Public Health Research. 2019; 7(4):151-156.

2. Chandra-Mouli, V, Patel, SV. Mapping the knowledge and understanding of menarche, menstrual hygiene and menstrual health among adolescent girls in low- and middle-income countries. Reproductive Health. 2017;14(1):30.

3. Stothard JR, Odiere MR, Phillips-Howard PA. Connecting female genital schistosomiasis and menstrual hygiene initiatives. Trends Parasitol. 2020;36(5):410-412

4. Alam MU, Luby SP, Halder AK, Islam K, Opel A, Shoab AK, et al. Menstrual hygiene management among Bangladeshi adolescent schoolgirls and risk factors affecting school absence: Results from a cross-sectional survey. BMJ Open. 2017;7(7):1-10.

5. Larsabal M, Sbidian E, Moyal-Barraco M, Dauendorffer JN, Dupin N, Richard MA, et al. a French prospective study assessing instantaneous prevalence, clinical features and impact on quality of life of genital psoriasis among patients consulting for psoriasis. Br J Dermatology. 2019;180(3):647-656.

6. Santra S. Assessment of knowledge regarding menstruation and practices related to maintenance of menstrual hygiene among the women of reproductive age group in a slum of Kolkata, West Bengal, India. Int J Community Med Public Health. 2017;4(3):708-712.

7. Priori R, Minniti A, Derme M, Antonazzo B, Brancatisano F, Ghirini S, et al. Quality of Sexual Life in Women with Primary Sjögren Syndrome. J Rheumatol. 2015;42(8):14271431.

8. Verbeek M, Hayward L. Pelvic Floor Dysfunction And Its Effect On Quality Of Sexual Life. Sex Med Rev. 2019;7(4):559564.

9. Pete PMN, Biguioh RM, Izacar AGB, Adogaye SBB, Nguemo C. Genital hygiene behaviors and practices: $A$ cross-sectional descriptive study among antenatal care attendees. J Public Health Afr. 2019;10(1):746.

10. Yang EJ, Beck KM, Sanchez IM, Koo J, Liao W. The impact of genital psoriasis on quality of life: a systematic review. Psoriasis (Auckl). 2018;8:41-47.
11. Crann SE, Cunningham S, Albert A, Money DM, O'Doherty KC. Vaginal health and hygiene practices and product use in Canada: a national cross-sectional survey. BMC Women's Health . 2018;18:52.

12. Eryılmaz G, Ege E. Genital hijyen davranışları envanterinin (GHDE) geliştirilmesi. Atatürk Üniversitesi Hemşirelik Yüksekokulu Dergisi. 2015;8(3):67-75.

13. Symonds T, Boolell M, Quirk F. Development of questionnaire on sexual quality of life in women. J Sex Marital Ther. 2005;31:385-97.

14. Tuğut N, Gölbaşı Z. Cinsel Yaşam Kalitesi Ölçeği - Kadın Türkçe Versiyonunun geçerlik ve güvenirlik çalışması. Cumhuriyet Tıp Dergisi. 2010;32:172-180.

15. Gözüyeşil E. Investigation of genital hygienebehavior:An example of slum area. Ortadogu Medical Journal. 2020;12(2):186-193

16. Calık KY, Erkaya R, İnce G, Yıldız NK. Genital Hygiene Behaviors of Women and Their Effect on Vaginal Infections. Clin Exp Health. 2020;10:210-216

17. Unal AKS, Çetinkaya F, Gozuyesil E. Adolescent Mothers' Postpartum Sex Life Quality: A Cross-Sectional Study. Konuralp Tıp Dergisi. 2020;12(2):282-289

18. Kaplan SE, Duman M, Yılmaz S. Sexual Life Quality and Marital Adjustment in Women With and Without Diabetes. Sexuality and Disability. 2020;38:625-635

19. Gölbaşı Z, Erenel AS. The quality of sexual life in women with gynaecological cancers. Arch Gynecol Obstet. 2012;285:1713-1717

20. Kavlak O, Saruhan A, Er S, Şen E, Sevil Ü. Determining the pregnancy genital hygiene behavior. Journal of Anatolia Nursing and Health Sciences 2010; 26(1): 53-63 (In Turkish).

21. Tüzmen $H$. Postpartum dönemde cinsel yaşam kalitesi ve ilişkili faktörler. Necmettin Erbakan Üniversitesi Sağlık Bilimleri Enstitüsü Hemşirelik Anabilim Dalı Yüksek Lisans Tezi. 2019

22. Mestoğulları E. 18-49 yaş arası üreme çağındaki evli kadınların cinsel fonksiyonlarından memnuniyet durumu, cinsel semptomları ve bu semptomların cinsel yaşam kalitesi üzerine etkisi. Trakya Üniversitesi, Sağlık Bilimleri Enstitüsü Hemşirelik Anabilim Dalı Yüksek Lisans Tezi. 2017

23. Engin B, Teke B. Genital Hygiene Behaviors of Midwifery Students. International Journal of Caring Sciences. 2020;13(3):2030

24. Durmuş MK, Zengin N. Kadınların Genital Hijyen Davranışlarının İncelenmesi. Sağlık Profesyonelleri Araştırma Dergisi. 2020;2(3):113-120

25. Çankaya S, Ege E. Evli kadınların genital hijyen davranışlarının ürogenital semptomlar ile Ilişkisi. Turkiye Klinikleri Journal of Nursing Sciences. 2014;6(2):94-101.

26. Çoban V. Postpartum dönemdeki kadınların cinsel yaşam kalitesi ve etkileyen faktörler. Cumhuriyet Üniversitesi, Sağlık Bilimleri Enstitüsü Doğum ve Kadın Hastalıkları Hemşireliği Anabilim Dalı Yüksek Lisans Tezi. 2012.

27. Başkan B. Inflamutuar barsak hastalığı olan kadınlarda cinsel yaşam kalitesinin değerlendirilmesi. Marmara Üniversitesi, Sağlık Bilimleri Enstitüsü İç Hastalıkları Hemşireliği Anabilim Dalı Yüksek Lisans Tezi. 2015.

28. Selimoğlu EŞ, Beydağ KD. Doğum Sonu Dönemde Emziren Kadınların Cinsel Yaşam Kalitesi. Acıbadem Üniversitesi Sağlık Bilimleri Dergisi. 2020;1:174-180. 